\title{
INTEGRASI NILAI-NILAI KARAKTER KEAGAMAAN ISLAM PADA BAHASA INDONESIA MELALUI MATERI PEMBELAJARAN PENYIMPULAN PIKIRAN, PENDAPAT DAN GAGASAN DALAM WAWANCARA DI SMA NEGERI 2 MAJENE SULAWESI BARAT
}

\author{
Mujizatullah \\ Peneliti Bidang Pendidikan Balai Penelitian dan Pengembangan Agama Makassar \\ Email : mujizatullah@kemenag.go.id
}

\begin{abstract}
Abstrak
Penelitian ini bertujuan untuk memberikan gambaran mengenai Integrasi Nilai Nilai Karakter Keagamaan Dalam Bahasa Indonesia melalui Materi Pembelajaran Penyimpulan Pikiran, Pendapat dan Gagasan dalam wawancara Di SMA Negeri 2 Majene Sulawesi Barat. Penelitian ini adalah penelitian kualitatif. Data dikumpulkan melalui wawancara kepada Kepala Sekolah dan guru Bahasa Indonesia. Penelitian menemukan Integrasi nilai-nilai karakter keagamaan adalah dengan mengintervensi atau menanamkan nilai-nilai karakter Keagamaan pada materi tersebut diatas melalui langkah-langkah pembelajaran mulai dari kegiatan awal, inti dan penutup. Nilai-nilai karakter Keagamaan yakni Aqidah Penanaman keyakinan kepada Allah dalam zat Nya, sifat dan asma Allah), keyakinan kepada kitab Allah, penanaman keyakinan terhadap malaikat, keyakinan kepada Nabi dan Rasul dan Akhlak meliputi sifat Shiddiq, yang berarti jujur. Nabi dan Rasul selalu jujur dalam perkataan dan perilakunya; Amanah, yang berarti dapat dipercaya dalam kata dan perbuatannya; Tabligh, yang berarti menyampaikan kebenaran kepada umat manusia; dan Fathanah, yang berarti cerdas atau pandai, sehing ga dapat mengatasi semua permasalahan yang dihadapinya.
\end{abstract}

Kata Kunci: Integrasi, Nilai-nilai karakter, Pembelajaran Bahasa Indonesia

\section{PENDAhuluan}

Pendidikan berfungsi mengembangkan kemampuan dan membentuk karakter serta peradaban bangsa yang bermartabat dalam mencerdaskan kehidupan bangsa bertujuan untuk berkembangnya potensi perserta didik agar menjadi manusia yang beriman dan bertakwa kepada Tuhan Yang Maha Esa, berakhlak mulia, sehat, berilmu, cakap, kreatif, mandiri, dan menjadi warga Negara yang demokratis serta bertanggung jawab. Hal ini sesuai dengan Undang-Undang Nomor 20 Tahun 2003 tentang Sisdiknas, pada pasal 3 .

Satuan pendidikan adalah salah satu komponen penting dalam pembangunan karakter, secara sistemik bersama dengan komponen pendidikan lainnya (Gede Raka, 2012:14). Pendidikan karakter keagamaan bagian dari karakter bangsa, salah satu bagian karakter bangsa adalah karakter keagamaan sementara untuk menciptakan hal tersebut diperlukan sistem yang termuat didalamnya komponen-komponen pendidikan yakni pelaksanaan manajemen lingkungan sarana dan prasarana kurikulum pendidik dan peserta didik. Hal tersebut berkaitan dengan pembentukan karakter peserta didik sehingga mampu bersaing, beretika, bermoral, sopan santun dan berinteraksi dengan masyarakat.
Pendidikan mengalami tantangan karena masih ada fenomena sosial yang menunjukkan perilaku yang tidak berkarakter. Dikalangan anak sekolah seperti tawuran, kekerasan (dekadensi moral) yang jauh dari moral agama, bahkan tidak memiliki mentalitas keagamaan yang baik sehingga diperlukan kembali pembentukan karakter keagamaan di sekolah. Pendekatannya secara sistematik dan integratif dengan melibatkan keluarga, satuan pendidikan, pemerintah, masyarakat sipil, anggota legislatif, media massa, dan dunia usaha. Pendidikan karakter semakin dibutuhkan dan mendapat pengakuan di masyarakat setelah dirasakan berbagai ketimpangan dan perilaku yang tidak berkarakter diantaranya terjadinya dekadensi moral pada komunitas pelajar sebagaimana yang telah dijelaskan sebelumnya. Hal ini mengindikasikan bahwa pendidikan agama dan moral tidak cukup dilakukan secara monolitik yang dilaksanakan hanya pada mata pelajaran tertentu, akan tetapi pendidikan karakter keagamaan dan moral sudah harus diintegrasikan pada semua mata pelajaran di sekolah.(Sungkowo, 2009:13).

Balai Penelitian dan Pengembangan Agama Makassar Tahun 2014 telah melakukan kegiatan Penelitian Implementasi pendidikan 
karakter pada madrasah Aliyah di kawasan timur Indonesia. Penelitian model pendidikan karakter keagamaan di Sulawesi Selatan telah dilakukan oleh Balai Penelitian dan Pengembangan Agama (2016). Selanjutnya pada Tahun 2017 telah dilakukan kegiatan penelitian ini Integrasi Nilai-Nilai Karakter Keagamaan Dalam Bahasa Indonesia melalui Materi Pembelajaran Penyimpulan Pikiran, Pendapat dan Gagasan dalam wawancara Di SMA Negeri 2 Majene Sulawesi Barat.

Secara umum permasalahan penelitian ini adalah "Bagaimana Integrasi Nilai Nilai Karakter Dalam Bahasa Indonesia melalui Materi Pembelajaran Penyimpulan Pikiran, Pendapat dan Gagasan dalam wawancara Di SMA Negeri 2 Majene Sulawesi Barat, dan faktor pendukung dan penghambat ,Tujuan Penelitian untuk menggambarkan Pengintegrasian Nilai Nilai Karakter Dalam Bahasa Indonesia melalui Materi Pembelajaran Penyimpulan Pikiran, Pendapat dan Gagasan dalam wawancara di SMA Negeri 2 Majene Sulawesi Barat. serta faktor pendukung dan penghambat .

\section{TINJAUAN PUSTAKA}

Karakter dapat pula dipahami sebagai sifat pribadi yang relatif stabil pada diri individu yang menjadi landasan bagi penampilan perilaku dalam standar nilai dan norma yang tinggi (Prayitno dan Belferik Manullang, 2011:47).

Istilah Pendidikan Karakter kemudian kembali menguat ketika Menteri Pendidikan dan Kebudayaan RI, Muhammad Nuh dalam pidatonya pada Hardiknas 2011 menekankan pentingnya Pendidikan Karakter, bahkan di tahun yang sama Badan Litbang dan Pengembangan pusat Kurikulum Kemendiknas RI menyusun delapan belas karakter pendidikan budaya karakter bangsa. Delapanbelas pendidikan karakter tersebut yaitu Religius, Jujur, Toleransi, Disiplin, Kerja keras, Kreatif, Mandiri, Demokratis, Rasa ingin tahu, Semangat kebangsaan, Cinta tanah air, Menghargai prestasi, Bersahabat/Komunikatif, Cinta damai, Gemar membaca, Peduli lingkungan, Peduli sosial, Tanggungjawab (Kemendiknas, Balitbang Pusat Kurikulum dan Perbukuan 2011:8). Ketika pendidikan karakter dihubungkan dengan nilai keagamaan tentu tidak serta merta dapat dilaksanakan dengan mudah. Ada yang menarik dari hasil riset Psychology Today yang menyimpulkan bahwa semakin Religius seseorang, semakin kurang ketertarikan mereka untuk terlibat dalam perilaku moral yang masih diragukan kebenarannya, dan semakin muda seseorang, semakin tinggi ketertarikan mereka untuk mengetahui dan mencoba perilaku moral yang sebenarnya masih diragukan kebenarannya (Gunawan, 2012 : 102). Integrasi pendidikan karakter keagamaan adalam proses pendidikan karakter keagamaan secara integrative pada muatan pembelajaran atau materi melalui langkahlangkah pembelajaran mulai dari kegiatan awal, inti dan penutup. Pengintegrasian pendidikan karakter dalam pembelajaran dapat dilakukan dengan pemuatan nilai-nilai karakter dalam semua mata pelajaran yang diajarkan di sekolah dan dalam pelaksanaan kegiatan pembelajaran. Untuk itu guru harus mempersiapkan pendidikan karakter mulai dari perencanaan, pelaksanaan, hingga evaluasinya. Pelaksanaan pendidikan karakter di sekolah perlu didukung oleh keteladanan guru dan orang tua murid serta budaya yang berkarakter. Peserta didik dalam proses pendidikan manusia yang memerlukan bimbingan (Hasballah, 2013:73).

Dalam ajaran Islam sendiri mengandung sistematika ajaran yang tidak hanya menekankan pada aspek keimanan, ibadah dan muamalah, tapi juga akhlak. Pengamalan ajaran Islam secara utuh (Kaffah) merupakan model karakter seorang muslim, bahkan dipersonifikasikan dengan model karakter Nabi Muhammad SAW, yang memiliki sifat Shiddiq, Tabliq, Amanah, Fathonah (Mulyasa, 2012:5).

Konfigurasi karakter dalam konteks totalitas proses psikologis dan sosial-kultural tersebut dapat dikelompokan dalam: Olah Hati (Spiritual and emotional development), Olah Pikir (intellectual development), Olah Raga dan Kinestetik (Physical and kinestetic development), dan Olah Rasa dan Karsa (Affective and Creativity development).

Keempat proses psiko-sosial (olah hati, olah pikir, olah raga, dan olahrasa dan karsa) tersebut secara holistik dan koheren memiliki saling keterkaitan dan saling melengkapi, yang bermuara pada pembentukan karakter yang menjadi perwujudan dari nilai-nilai luhur. 
Sifat-sifat khusus (akhlak) yang dimiliki oleh Nabi Muhammad Saw maupun para nabi dan rasul yang lain adalah Shiddiq, yang berarti jujur. Nabi dan Rasul selalu jujur dalam perkataan dan perilakunya, Amanah, yang berarti dapat dipercaya dalam kata dan perbuatannya, Tabligh, yang berarti menyampaikan apa saja yang diterimanya dari Allah (wahyu) kepada umat manusia, Fathanah, yang berarti cerdas atau pandai, sehingga dapat mengatasi semua permasalahan yang dihadapinya, Maeshum, yang berarti tidak pernah berbuat dosa atau maksiat kepada Allah. Sebagai manusia bisa saja nabi berbuat salah dan lupa, namun lupa dan kesalahannya selalu mendapat teguran dari Allah sehingga akhirnya dapat berjalan sesuai dengan kehendak Allah.

Sifat Shiddiq menjadi modal bagi generasi muslim yang memiliki kemampuan olah hati (kecerdasan spiritual). Yaitu generasi yang memiliki sifat jujur, ikhlas, mensyukuri atas apa yang ada, menerima (tawakkal) atas apa yang telah terjadi, serta selalu berlaku adil. Sifat Fathonah merupakan wujud bagi generasi muslim yang memiliki kemampuan olah fikir (kecerdasan intelektual) yang tinggi. Memiliki visi jauh kedepan, cerdas, kreatif dan terbuka. Sifat Amanah menjadi simbol bagi generasi muslim yang memiliki kegigihan dalam bertindak, semangat. Senantiasa bekerja keras, disiplin dan bertanggung jawab. Sifat Tabligh merupakan perwujudan bagi generasi muslim yang memiliki kemampuan olah rasa/karsa (kecerdasan emosi) yang matang. Mereka senantiasa perduli dengan penderitaan orang lain, memiliki kepekaan untuk selalu membantu orang yang membutuhkan, senang bergotong royong dan bertindak demokratis dalam memutuskan sesuatu. Berdasarakan Analisa dapat disimpulkan bahwa Rasulullah memiliki 4 sifat yang sangat tepat dan menjadi model serta karakter yang dapat diikuti di sepanjang waktu.

Menurut Gorys Keraf (2004 : 1), bahasa adalah alat komunikasi antara anggota masyarakat berupa simbol bunyi yang dihasilkan oleh alat ucap manusia. Ketika anggota masyarakat menginginkan untuk berkomunikasi dengan sesamanya, maka orang tersebut akan menggunakan suatu bahasa yang sudah biasa digunakannya untuk menyampaikan sesuatu informasi. Wahyu Wibowo (2001) Tidak dapat dipungkiri lagi bahwasanya bahasa nasional dan bahasa negara di Indonesia adalah Bahasa Indonesia. Kedua kedudukan tersebut sangatlah penting dan harus terpenuhi fungsinya. Jika ada salah satu yang tidak terpenuhi maka fungsi Bahasa Indonesia sebagai bahasa pemersatu akan pudar dan akan sirna. Di dalam kedudukannya sebagai bahasa negara, Bahasa Indonesia berfungsi sebagai Bahasa resmi kenegaraan, Bahasa pengantar dalam dunia pendidikan, Alat perhubungan di tingkat nasional untuk kepentingan perencanaan dan pelksanaan pembangunan, Alat pengembangan kebudayaan, ilmu pengetahuan dan teknologi ( Zaenal Arifin, 2008:13).

Ragam bahasa adalah pembagian bahasa yang ditinjau dari bagaimana cara bahasa itu diutarakan oleh orang yang melakukan komunikasi. Lamuddin Finoza (2002:3) memaparkan bahwa ragam bahasa menjadi sangat banyak jumlahnya karena pemilihan corak bahasa yang dipakai seseorang untuk mengomunikasikan sesuatu bergantung kepada tiga hal berikut ini Cara berkomunikasi lisan atau tulisan, Cara pandang penutur terhadap mitra komunikasinya, Topik yang dibicarakan/dituliskan.

Bahasa Indonesia merupakan bahasa Nasional dan bahasa Negara. Sebagai bahasa Nasional, ia berfungsi sebagai lambang kebanggaan nasional, alat pemersatu berbagai suku bangsa dengan latar belakang sosial budaya dan bahasa, pengembang kebudayaan, pengembang ilmu pengetahuan dan teknologi, serta alat perhubungan dalam kepentingan pemerintahan dan kenegaraan. Sebagai bahasa Negara, ia berfungsi sebagai bahasa pengantar di lembaga-lembaga pendidikan, pengembang kebudayaan, pengembang ilmu pengetahuan dan teknologi, dan juga sebagai alat perhubungan pemerintah dan kenegaraan. Hal ini diatur dalam UUD 1945 pada pasal 36, yaitu "Bahasa Negara ialah Bahasa Indonesia". Peserta didik akan tahu bahwa Bahasa yang mereka gunakan mencerminkan nilai-nilai sosial budaya luhur bagnsa Indonesia. Sebagaimana yang dikemukakakn Muslich dan I Gusti Ngurah Oka (2010: 31), bahwa dengan menggunakan Bahasa Indonesia akan dapat diketahui perangai, sifat, dan waka kita sebagai pemakainya. Untuk itu, kita harus menjaganya jangan sampai ciri kepribadian kita tidak mencerminkan nilainilai luhur sebagai identitas bangsa Indonesia. 
\begin{tabular}{lccr}
\multicolumn{1}{c}{ Integrasi } & nilai-nilai & karakter & dalam \\
pembelajarn & Bahasa & Indonesia & dapa \\
diwujudkan jika guru & memahami & bahwa \\
pemebelajaran Bahasa & Indonesia & yang \\
dberikan guru dalam & rangka melatih
\end{tabular} keterampilan berbahasa peserta didik baik secara lisan maupun tertulis yang sesuai dengan fungsinya. Namun kenyataannya, guru sering terjebak dalam pembelajaran bahasa Indonesia yang lebih menekankan tentang teori kebahasaan. Sebagaimana yang dikemukakan Slamet (2007: 6), bahwa pengajaran bahasa Indonesia adalah pengajaran keterampilan berbahasa bukan pengajaran tentang kebahasaan. Teori-teori bahasa hanya sebagai pendukung atau penjelas dalam konteks, yaitu yang berkaitan dengan keterampilan tertentu yang tengah diajarkan. Untuk itu, proses pembelajaran Bahasa Indonesia sebagaimana yang dituangkan dalam Standar Isi mata pelajaran Bahasa Indonesia (Mendiknas, 2006: 232) menekankan sebagai berikut: Berkomunikasi secara efektif dan efisien sesuai dengan etika yang berlaku, baik secara lisan maupun tulis, Menghargai dan bangga menggunakan bahasa Indonesia sebagai bahasa persatuan dan bahasa Negara, Memahami bahasa Indonesia dan menggunakannya dengan tepat dan kreatif untuk berbagai tujuan, Menggunakan bahasa Indonesia untuk meningkatkan kemampuan intelektual, serta kematangan emosional dan social, Menikmati dan memanfaatkan karya sastra untuk memperluas wawasan, memperhalus budi pekerti, serta meningkatkan pengetahuan dan kemampuan berbahasa, Menghargai dan membanggakan sastra Indonesia sebagai khazanah budaya dan intelektual manusia Indonesia.

Dasar Hukum Undang-Undang No.20 Tahun 2003, tentang Sistem Pendidikan Nasional , Peraturan Menteri Pendidikan dan Kebudayaan No. 58 Tahun 2014 tentang Kurikulum 2013 Sekolah Menengah Pertama /Madrasah Tsanawiah, Peraturan Menteri Pendidikan dan Kebudayaan No. 103 Tahun 2014, tentang Pendidikan Dasar dan Pendidikan Menengah.

Ruang Lingkup Pengintegrasian Nilai Nilai Karakter Dalam Bahasa Indonesia melalui Materi Pembelajaran Penyimpulan Pikiran, Pendapat dan Gagasan dalam wawancara yang menyentuh sikap dan perilaku yang terhimpum dalam sifat shiddiq, fathonah, amanah, tabligh.
Ruang linkup pengintegrasian nilai-nilai karakter keagamaana pada pelajaran tersebut mencakup akidah, akhlak, ibadah, berwawasan, semangat keagamaan dan semangat kepedualian social. Secara umum nilai-nilai termaktub dalam nilai-nilai agama, nilai-nilai social, nilai-nilai budaya dan karakter bangsa. Penanaman nilai-nilai karakter keagamaan tersebut diintegrasikan dalam materi pembelajaran bahasa Indonesia melalui langkah-langkah pembelajaran mulai dari kegiatan awal, inti dan penutup . Pelaksanaan proses belajar mengajar di dalam kelas terkait dengan penerapan pengintegrasian atau penanaman oleh guru diharapkan adanya intervensi dalam hal nilainilai karakter keagamaan.

\section{METODE PENELITIAN}

Penelitian ini menggunakan pendekatan kualitatif, peneliti menjadi bagian dari key instrument (Bogdan, 1982:27). Peneliti mencoba memperoleh gambaran tentang Pengintegrasian Nilai Nilai Karakter Dalam Bahasa Indonesia melalui Materi Pembelajaran Penyimpulan Pikiran, Pendapat dan Gagasan dalam wawancara secara integratif dan faktor pendukung dan penghambat . Teknik pengumpulan data penelitian ini dilakukan dengan jenis instrument yaitu observasi sebagai metode ilmiah diartikan dengan pengamatan dan pencatatan dengan sistematis fenomenafenomena yang diselidiki . Observasi dilakukan dalam rangka pengamatan dan mencatat data atau informasi yang diperlukan sesuai dengan masalah yang didapatkan meliputi kegiatan proses pembelajaran, proses Pengintegrasian Nilai Nilai Karakter Dalam Bahasa Indonesia melalui Materi Pembelajaran Penyimpulan Pikiran, Pendapat dan Gagasan dalam wawancara.

Wawancara digunakan untuk memperoleh data terkait dengan komponen sekolah yaitu kepala sekolah dan guru Bahasa Indonesia sekolah menengah atas. Dokumen untuk memperoleh pengadministrasian sekolah , komposisi guru, peserta didik dan fasilitas pendidikan yang ada di sekolah. Angket dilakukan untuk mengetahui sejauh mana validitas dan efektifitas perencanaan pembelajaran yang dirancang oleh guru dalam pelaksanaan pendidikan karakter keagamaan . Focus Group Discussion dilakukan dalam 
rangka menghasilkan data dan cakrawala melalui interaksi antar anggota dan kelompok (Organ, 1998 , 12)dengan mengumpulkan orang dari latar pengalaman yang sama untuk mendiskusikan Pengintegrasian Nilai Nilai Karakter Dalam Bahasa Indonesia melalui Materi Pembelajaran Penyimpulan Pikiran, Pendapat dan Gagasan dalam wawancara. FGD dalam penelitian ini dilakukan dengan guru bahasa Indonesia dan Kepala Sekolah karena mereka mempunyai informasi tentang hal tersebut di atas.

Analisis data yang digunakan dalam penelitian ini yaitu melalui pengumpulan data yang bersifat kualitatif untuk disajikan dan direduksi data yang selanjutnya diambil kesimpulan. Teknik analisis data yang diguanakan model analisis yang dilakukan oleh Staruss $(2007,100)$ yaitu menghubungkan antara kategori dan sub kategori untuk dicari pola-polanya . Langkah yang digunakan reduksi data, penyajian data dan verifikasi data (Sugiyono, 2007 : 92). Langkah-langkah analisis data membuat kategori masalah berdasarkan wawancara dan temuan-temuan dari hasil pengumpulan data dan mengkategorikan data dengan mereduksi data . Dari hasil pengumpulan data tersebut diambil pengertian-pengertian yang lebih konprehensif dan mendalam untuk diambil kesimpulan secara obyektif dan sistematis.(Sujana, 1989 : 196).

\section{PEMBAHASAN}

\section{Profil SMA Negeri 2 Majene Sulawesi Barat.}

SMA Negeri 2 Majene tepat berada di alamat Jl.Chaeril Anwar No. 25 Majene Desa/Kelurahan Lembang Kecamatan Banggae Timur Kabupaten Majene , Kepala Sekolah Drs.H.Mahyuddin Laha, M.Si. Luas sekolah 19.947 M2 . Jumlah siswa sebanyak 815 orang terdiri dari Laki-laki 374 dan Perempuan 441 siswa. Data pendidik dan tenaga pendidikan, jumlah tenaga pendidik 56 orang PNS dan Non PNS dan Tenaga Kependidikan sebanyak 10 PNS dan 36 orang Non PNS. Keadaan asset terdiri dari Ruang Guru dan Kepala Sekolah, Laboratorium, Perpustakaan, Meubiler, Lapangan Olah Raga , Ruang Ekstrakurikuler, Listrik dan internet, Alat Peraga dan Praktek Siswa, Komputer dan kelengkapannya.

Rencana Pelaksanaan Pembelajaran ,Mata Pelajaran Bahasa Indonesia,
Kelas/Semester VII/1, Standar Kompetensi Mendengarkan, wacana lisan melalui kegiatan mendengarkan berita, Kompetensi dasar , Menyimpulkan isi berita yang dibacakan dalam beberapa kalimat, Alokasi waktu 2 x 40 menit, Tujuan Pembelajaran, Peserta didik dapat menunjukkan pokok-pokok berita yang didengarkan, Peserta didik dapat menyarikan pokok-pokok berita menjadi isi berita, Peserta didik dapat menyimpulkan isi berita dalam satu alinea. Karakter siswa yang diharapkan sifat Amanah, Shiddiq, yang berarti jujur. Nabi dan Rasul selalu jujur dalam perkataan dan perilakunya; Amanah, yang berarti dapat dipercaya dalam kata dan perbuatannya; Tabligh, yang berarti menyampaikan kebenaran kepada umat manusia; dan Fathanah, yang berarti cerdas atau pandai, sehingga dapat mengatasi semua permasalahan yang dihadapinya

Materi Pembelajaran, Penyimpulan pikiran, pendapat dan gagasan dalam wacana. Metode Pembelajaran, Tanya jawab, diskusi dan penugasan, Langkah-langkah Kegiatan Pembelajaran,Kegiatan Awal, Apersepsi Peserta didik Membacakan teks berita, Peserta didik mendengarkan teks berita yang dibacakan, Peserta didik diminta bertanya tentang manfaat berita yang dibacakan, Motivasi Menjelaskan isi berita yang dibacakan dalam beberapa kalimat, Kegitan Inti, Eksplorasi Dalam kegiatan eksplorasi, guru melibatkan peserta didik mencari informasi yang luas dan dalam tentang topik/tema materi yang akan dipelajari dengan menerapkan prinsip alam takambang jadi guru dan belajar dari aneka sumber,menggunakan beragam pendekatan pembelajaran, media pembelajaran, dan sumber belajar lain, memfasilitasi terjadinya interaksi antarpeserta didik serta antara peserta didik dengan guru, lingkungan, dan sumber belajar lainnya, melibatkan peserta didik secara aktif dalam setiap kegiatan pembelajaran; dan memfasilitasi peserta didik melakukan percobaan di laboratorium, studio, atau lapangan.

Elaborasi, dalam kegiatan elaborasi, guru membiasakan peserta didik membaca dan menulis yang beragam melalui tugas-tugas tertentu yang bermakna, memfasilitasi peserta didik melalui pemberian tugas, diskusi, dan lain-lain untuk memunculkan gagasan baru baik secara lisan maupun tertulis ,memberi 
kesempatan untuk berpikir, menganalisis, menyelesaikan masalah, dan bertindak tanpa rasa takut, memfasilitasi peserta didik dalam pembelajaran kooperatif dan kolaboratif, memfasilitasi peserta didik berkompetisi secara sehat untuk meningkatkan prestasi belajar, memfasilitasi peserta didik membuat laporan eksplorasi yang dilakukan baik lisan maupun tertulis, secara individual maupun kelompok, memfasilitasi peserta didik untuk menyajikan hasil kerja individual maupun kelompok, memfasilitasi peserta didik melakukan pameran, turnamen, festival, serta produk yang dihasilkan, memfasilitasi peserta didik melakukan kegiatan yang menumbuhkan kebanggaan dan rasa percaya diri peserta didik. Konfirmasi dalam kegiatan konfirmasi, guru memberikan umpan balik positif dan penguatan dalam bentuk lisan, tulisan, isyarat, maupun hadiah terhadap keberhasilan peserta didik, memberikan konfirmasi terhadap hasil eksplorasi dan elaborasi peserta didik melalui berbagai sumber, memfasilitasi peserta didik melakukan refleksi untuk memperoleh pengalaman belajar yang telah dilakukan, memfasilitasi peserta didik untuk memperoleh pengalaman yang bermakna dalam mencapai kompetensi dasar berfungsi sebagai narasumber dan fasilitator dalam menjawab pertanyaan peserta didik yang menghadapi kesulitan, dengan menggunakan bahasa yang baku dan benar, membantu menyelesaikan masalah, memberi acuan agar peserta didik dapat melakukan pengecekan hasil eksplorasi, memberi informasi untuk bereksplorasi lebih jauh, memberikan motivasi kepada peserta didik yang kurang atau belum berpartisipasi aktif.

Karakter siswa yang di harapkan Pengintegrasian nilai-nilai karakter Keagamaan dalam pembelajaran bahasa Indonesia akan memberikan andil kepada peserta didik dalam bertindak tutur yang memegang nilai-nilai luhur budaya bangsa Indonesia.

Kegiatan Penutup, dalam kegiatan penutup, guru bersama-sama dengan peserta didik dan/atau sendiri membuat rangkuman/simpulan pelajaran, melakukan penilaian dan/atau refleksi terhadap kegiatan yang sudah dilaksanakan secara konsisten dan terprogram, memberikan umpan balik terhadap proses dan hasil pembelajaran, merencanakan kegiatan tindak lanjut dalam bentuk pembelajaran remedi, program pengayaan, layanan konseling dan/atau memberikan tugas baik tugas individual maupun kelompok sesuai dengan hasil belajar peserta didik, menyampaikan rencana pembelajaran pada pertemuan berikutnya.

Karakter siswa yang di harapkan dengan menanamkan nilai Aqidah Penanaman keyakinan kepada Allah dalam zat Nya, sifat dan asma Allah, keyakinan kepada kitab Allah, penanaman keyakinan terhadap malaikat, keyakinan kepada Nabi dan Rasul.

Sumber Belajar ; Bagan identifikasi pengalaman, Gambar, VCD, Narasumber, Buku Pelajaran Bahasa dan Sastra Indonesia. Penilaian dilaksanakan selama proses dan sesudah pembelajaran. Indikator pencapaian Mampu menulis isi/sari berita yang didengarkan/dibacakan, Mampu menyimpulkan isi/sari berita dalam satu alinea. Penilaian dilakukan dengan menggunakan teknik penilaian Tes Tulis, bentuk instrumen yakni uraian, dan soal/instrumen yakni Tulislah minimal lima isi/sari berita dari sepuluh isi/sari berita yang dibacakan, Tulislah simpulan isi berita yang kamu dengarkan ke dalam satu alinea. Butir soal Tulislah minimal 3 pokok berita yang terdapat dalam teks berita yang dibacakan dengan skor maksimal 3, Tunjukkan intisari pokok-pokok beritanya dengan skor maksimal 4, Tulislah simpulan isi berita yang kamu dengarkan ke dalam satu alinea dengan skor maksimal 3. Jumlah skor maksimal 10.

Kriteria Penilaian. Soal Nomor 1 ,Apabil Peserta didik menjawab satu dari tiga pokok berita, Apabila hanya dua yang benar, Apabila Peserta didik menjawab lengkap dan benar. Soal Nomor 2, Apabila Peserta didik menjawab benar nilai 4, Apabila Peserta didik menjawab kurang sempurna nilai 2, Apabila Peserta didik salah diberi nilai 1. Soal Nomor 3 , Apabila Peserta didik dapat menyimpulkan dengan benailai 3, Apabila Peserta didik dapat menyimpulkan tetapi kurang sempurna nilai 2 , Apabila Peserta didik salah diberi nilai 1.

Pengitegrasian nilai -nilai karakter keagamaan pada pelajaran Bahasa Indonesia dengan mengintervensi nilai-nilai karakter keagamaan pada materi Pembelajaran Penyimpulan Pikiran, Pendapat dan Gagasan dalam wawancara melalui langkah-langkah pembelajaran mulai dari kegiatan awal, inti dan penutup. Nilai-nilai karakter keagamaan 
tersebut adalah masalah Aqidah Penanaman keyakinan kepada Allah dalam zat Nya, sifat dan asma Allah), keyakinan kepada kitab Allah, penanaman keyakinan terhadap malaikat, keyakinan kepada Nabi dan Rasul, Akhlak. Akhlak kepada guru dan sesama teman, dan akhlak kepada lingkungan. Ibadah, Membaca basmalah setiap memulai kegiatan, berdoa, shalat wajib dan shalat jamaah, Berwawasan Luas (Kecerdasan Emosional dan Spritual), Peserta didik senang dan bersemangat ketika disapa oleh guru, Spirit Keagamaan dan Kepedulian Sosial dan Lingkungan, Sikap amal makruf terhadap teman yang merusak nama sekolah dan perilaku ketika teman membutuhkan bantuan. Kaitannya dengan hal tersebut penanaman nilai-nilai karakter keagamaan yang ditanamkan kepada siswa pada pelajaran Bahasa Indonesia dengan materi tersebut di atas mengucapkan salam setiap bertemu guru dan teman di lingkungan sekolah. Peserta didik dibiasakan membaca alquran selama lima sampai dengan sepuluh menit sebelum pelajaran dimulai. Peserta didik selalu memakai pakaian rapih ke sekolah, berdoa ketika memulai dan mengakhiri pelajaran, peserta didik selalu di ingatkan oleh guru Bahasa Indonesia untuk ikut berjamaah di mushallah pada saat shalat dhuhur dilanjutkan dengan kultum dan peserta didik membuang sampah pada tempatnya.

Faktor pendukung dan penghambat. Faktor pendukung pembelajaran Bahasa Indonesia adalah pembelajaran tentang keterampilan berbahasa bukan pembelajaran tentang kebahasaan. Proses pembelajaran yang dilaksanakan, dengan empat aspek keterampilan berbahasa, yaitu bahasa Indonesia yang baik dan benar dengan mengintegrasikan nila-nilai karakter keagamaan disetiap aspek keterampilan tersebut. Faktor penghambat rendahnya Kompetensi Profesional Guru Bahasa Indonesia dalam mengintegrasikan nilai- nilainilai Karakter Keagamaan pada materi yang diajarkan.

\section{KESIMPULAN}

Integrasi nilai-nilai karakter keagamaan Islam pada pelajaran Bahasa Indonesia melalui materi pembelajaran penyimpulan pikiran, pendapat dan gagasan dalam wawancara di
SMA Negeri 2 Majene Sulawesi Barat adalah dengan mengintervensi atau menanamkan nilai-nilai karakter keagamaan Islam pada materi tersebut diatas melalui langkah-langkah pembelajaran mulai dari kegiatan awal, inti dan penutup. Nilai-nilai karakter keagamaan yakni Aqidah Penanaman keyakinan kepada Allah dalam zat Nya, sifat dan asma Allah), keyakinan kepada kitab Allah, penanaman keyakinan terhadap malaikat, keyakinan kepada Nabi dan Rasul dan Akhlak meliputi sifat Shiddiq, yang berarti jujur. Nabi dan Rasul selalu jujur dalam perkataan dan perilakunya; Amanah, yang berarti dapat dipercaya dalam kata dan perbuatannya; Tabligh, yang berarti menyampaikan kebenaran kepada umat manusia; dan Fathanah, yang berarti cerdas atau pandai, sehingga dapat mengatasi semua permasalahan yang dihadapinya.

Faktor pendukung dan penghambat. Faktor pendukung pelajaran pendidikan keagamaan mengenai Aqidah dan Akhlak tidak hanya dilaksanakan secara monolitik akantetapi dapat dilakukan secara integratif yakni Pengintegrasian nilai-nilai karakter keagamaan Islam Shiddiq, Amanah, Tabligh dan Fathanah dalam pembelajaran bahasa Indonesia akan memberikan andil kepada peserta didik dalam bertindak tutur yang memegang nilai-nilai luhur budaya bangsa Indonesia. Faktor penghambat rendahnya Kompetensi Profesional Guru Bahasa Indonesia dalam mengintegrasikan nilai- nilai-nilai Karakter Keagamaan pada materi yang diajarkan dan direkomendasikan perlunya peningkatan kompetensi professional guru dalam mengintegrasikan nilai-nilai karakter keagamaan Islam melalui kegiatan Pendidikan dan Pelatihan Peningkatan Mutu SDM Guru.

\section{DAFTAR PUSTAKA}

Arifin, E. Zaenal dan Tasai S. Amran.2009Cermat Berbahasa Indonesia Untuk Perguruan Tinggi. Jakarta:Akademika Pressindo.

Azra, Azyumar. 2012. Pendidikan Karakter Teguhkan Pribadi Bangsa. Makalah. Disajikan di UNNES Semarang, Minggu 23 September 2012.

Finoza, Lamuddin. 2002.Komposisi Bahasa Indonesia.Cetakan ke-8. Jakarta: Diksi Insan Mulia. 
Gede Raka, 2012. Pendidikan Moral dan Spiritual Dalam Membangun Karakter Bangsa (Analisis Kitab Nashoihul 'Ibad Karya Syaikh Nawawi (I-Bantani ) Puslitbang Pendidikan Agama dan Keagamaan, Badan Litbang dan Diklat Kementerian Agama RI. Jakarta.

Gunawan, Heri. 2012, Pendidikan Karakter, Konsep dan Implementasi, Bandung : Alfabeta.

Hasbalah, 2013. Dasar-Dasar Ilmu Pendidikan. Jakarta : Raja Grafindo Persada

Keraf, Gorys. 2004.Komposisi Sebuah Pengantar Kemahiran Bahasa. Flores: Nusa Indah.

Kemendiknas, Balitbang Pusat Kurikulum dan Perbukuan 2011.

Mulyasa. 2011. Manajemen Pendidikan Karakter. Jakarta: Bumi Aksara.

Muslich, Masnur dan I gusti Ngurah Oka. 2010. Perencanaan Bahasa pada Era Globalisasi. Jakarta: Bumi Aksra.

Muslich, Masnur. 2011. Pendidikan Karakter: Menjawab Tantangan Krisis Multidimensi. Jakarta: Bumi Aksara.

Sagala, Syaiful. 2009. Konsep dan Makna Pembelajaran. Bandung: Alfabeta.

Slamet, St. Y.. 2007. Dasar-Dasar Pembelajaran Bahasa dan Sastra Indonesia di Sekolah Dasar. Surakarta: LPP UNS dan UPT.

Sungkowo, 2014. Panduan Pencegahan dan Penanggulangan Penyimpangan Perilaku Siswa Sekolah Menengah Atas, Departemen Pendidikan Nasional, Direktorat Jenderal Manajemen Pendidikan Dasar dan Menengah Direktorat Pembinaan Sekolah Menengah Atas. Jakarta.

Wibowo, Wahyu.2001.Manajemen Bahasa. Jakarta: Gramedia. 